\title{
SCREENING OF PRESCHOOL CHILDREN FOR BLOOD LEAD LEVELS AT KIMS HOSPITAL
}

\author{
Chandrakala P1, A. C. Ramesh², Sharanya R ${ }^{3}$
}

\section{HOW TO CITE THIS ARTICLE:}

Chandrakala P, A. C. Ramesh, Sharanya R. "Screening of Preschool Children for Blood Lead Levels at KIMS Hospital". Journal of Evolution of Medical and Dental Sciences 2014; Vol. 3, Issue 11, March 17;

Page: 2706-2710, DOI: $10.14260 /$ jemds/2014/2196

\begin{abstract}
OBJECTIVE: to screen preschool children for blood lead level with an objective to estimate ZPP levels among preschool children attending OPD and admitted to wards and to confirm blood lead levels in children whose ZPP is>_35ugm/dl. METHODS: hospital based descriptive study conducted at KIMS, BANGALORE from $1^{\text {st }}$ July 2007 to $31^{\text {st }}$ July 2008. 100 preschool children aged between 1 to 6 years who came to OPD and were admitted, were chosen randomly. Data was collected in a simple questionnaire which included demographic, clinical, investigations. Venous blood, $2 \mathrm{ml}$ was drawn and estimated for ZPP. If ZPP >_ 35ugm/dl, then blood samples were estimated for blood lead levels. The data collected in this study was analyzed statistically using chi square test and standard normal variate (Z) test for proportions. RESULTS: Out of 100 children, 37\% of them had ZPP > $35 \mathrm{ugm} / \mathrm{dl}$.Among these $20 \%$ had blood level more $>10 \mathrm{ugm} / \mathrm{dl}$. Socio economic status affects lead exposure with poor socio economic status group being most prone for lead absorption. Among the $20 \%$ who had blood lead levels $>10 \mathrm{ugm} / \mathrm{dl}, 15 \%$ of them belonged to urban area and $5 \%$ belonged to rural area. Location of the house of children in this study was observed that in industrial area were $85 \%$, mechanic factory were $7 \%$, battery factory were $3 \%$, automobile and cottage industry were $2 \%$. Among 100 children, 57 had hemoglobin $\%$ of $>10$ gm and 43 were anemic having hemoglobin $<10$ gm $\%$. CONCLUSION: As lead poisoning patients can be asymptomatic or symptomatic with only vague presentations, screening of blood lead levels should be made as a routine investigation. Awareness should be created regarding the sources of lead, its exposure and potential health effects.
\end{abstract}

KEYWORDS: Preschool children ZPP - blood lead levels lead poisoning - screening anemia.

INTRODUCTION: Lead is a heavy nonessential toxic metal, known since ancient days. ${ }^{1} \mathrm{~A}$ greek physician in $2^{\text {nd }}$ century BC wrote," lead makes the mind give way" .But it is still a pervasive environmental poison that affects virtually every system in the body. It is particularly harmful to the developing brain and nervous system. ${ }^{2}$ Lead is biodegradable; therefore lead deposited in the environment remains, accumulates and gets distributed around the areas. It gets dispersed into air, food, soil, dust and water .Children of all socio economic backgrounds in all geographic areas experience unacceptably high lead exposures.

Children are at a higher risk for lead exposure because, they have more hand to mouth activity than adults and they absorb more lead than adults.2 Lead is absorbed by ingestion, inhalation and through skin. Approximately 150 -300 ugm of lead is ingested through oral route and 10-20 ugm is inhaled through respiratory tract. ${ }^{3}$

$90 \%$ of the lead absorbed is stored in bones and $10 \%$ of lead is stored in soft tissues like brain i.e. basal ganglia and grey matter, liver, kidney, teeth and hair .It affects both calcium metabolism and hemoglobin synthesis. 
The sources of lead are lead based paint (most common high dose source), soil and dust, drinking water (contamination in the distribution system), parental occupations and hobbies, air and food.

Majority of side effects of lead poisoning is silent and children may be asymptomatic. Therefore vast majority go undiagnosed and untreated. It causes effects on GI system (loss of appetite, epigastric distress, abdominal colic and constipation), nervous system (encephalopathy, peripheral neuropathy, deafness, ataxia, headache, insomnia, coma), neuromuscular system (muscular weakness, paralysis, foot drop, wrist drop), hematopoietic system (hypochromic microcytic anemia, bone marrow suppression), reproductive system (sterility in males, menstrual irregularities, still birth) ${ }^{4}$

Most protoporphyrin in erythrocytes (90\%) exists as zinc protoporphyrin (ZPP).This fraction is measured by hematofluorometers. Extraction method measures all the protoporphyrins present, but strips the zinc from ZPP during the extraction process, for this reason results are sometimes referred to as (zinc) free erythrocyte protoporphyrin (FEP) .So results reported as EP, ZPP or FEP all reflects essentially same analyte. ${ }^{5}$

If FEP is >_35 ugm/dl, it indicates anemia or lead poisoning. But FEP $<35 \mathrm{ugm} / \mathrm{dl}$ does not rule out lead poisoning because it is not the only criteria.

The venous blood sample, $1 \mathrm{ml}$, of patients whose FEP is >_35 ugm/dl is added to a test tube containing mete exchange reagent. This is used to detect blood lead level with help of ESA analyzer, which is calibrated using controls. ${ }^{5}$

The blood lead level thus analyzed >_ $10 \mathrm{ugm} / \mathrm{dl}$ is considered to be as lead poisoning defined by Centre for Disease Control. ${ }^{6}$

The aim of our study was to screen preschool children for blood lead level with an objective to estimate ZPP levels among preschool children attending OPD and admitted to wards and to confirm blood lead levels in children whose ZPP is>_35ugm/dl. The clinical epidemiological profile of children was studied also.

MATERIAL AND METHODS: The present study was conducted at KIMS, BANGALORE from 1stjjuly 2007 to $31^{\text {st }}$ July 2008 as a hospital based descriptive study.100 preschool children aged between 1 to 6 years who came to OPD and were admitted, were chosen randomly. Data was collected in simple questionnaire which included demographic, clinical, investigations. Venous blood, $2 \mathrm{ml}$ was drawn and estimated for ZPP. If ZPP >_ 35ugm/dl, then blood samples were estimated for blood lead level. The data collected in this study was analyzed statistically using chi square test and standard normal variate $(Z)$ test for proportions.

RESULTS: Out of 100 children, $37 \%$ of them had ZPP > 35 ugm/dl .Among these $20 \%$ had blood level more $>10 \mathrm{ugm} / \mathrm{dl}$, out of which $13 \%$ were males and $7 \%$ were females. The socio economic status of parents of children observed in this study belonging to lower middle class were $70 \%$, lower class $18 \%$, upper middle class were 7\% and upper lower class were 5\% . In the present study out of 100 children, among $20 \%$ who had blood lead levels greater than $35 \mathrm{ugm} / \mathrm{dl}, 12 \%$ of them belonged to lower middle class, $5 \%$ of them were from lower class, $2 \%$ of them were from upper class and $1 \%$ of them were from upper middle class. 


\begin{tabular}{|c|c|c|}
\hline SES CLASS & CHILDREN & TEST OF SIGNIFICANCE \\
\hline Upper lower & 5 & NS \\
\hline Upper middle & 7 & $\mathrm{P}<0.001$ \\
\hline Lower middle & 70 & $\mathrm{NS}$ \\
\hline Lower & 18 & $\mathrm{P}<0.001$ \\
\hline
\end{tabular}

TABLE 1: EFFECT OF SOCIO ECONOMIC STATUS ON LEAD LEVELS

In the present study out of 100 children, $20 \%$ of them had blood lead levels $>10 \mathrm{ugm} / \mathrm{dl}$. Among them it is observed that $12 \%$ of children had normal nutritional status, $4 \%$ of children belonged to G1 and G2 and 2\% to G3 malnutrition status according to IAP classification.

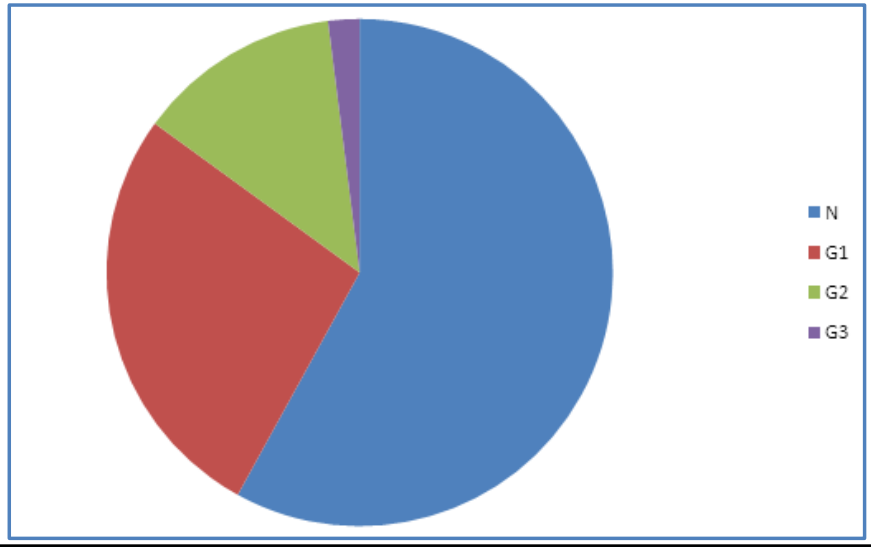

\section{FIGURE 1: IMPACT OF NUTRITIONAL STATUS ON LEAD POISONING}

In the present study out of 100 children $20 \%$ of them had blood lead levels $>10 \mathrm{ugm} / \mathrm{dl}$. Among them it is observed that $15 \%$ of them belonged to urban area and 5\% belonged to rural area. Location of the house of children in this study was observed that in industrial area were 85\%, mechanic factory were $7 \%$, battery factory were $3 \%$, automobile and cottage industry were $2 \%$.

In the present study the clinical presentation of 100 preschool children, fever (50\%) was the commonest presentation followed by cough in $24 \%$. Other clinical presentation were pain abdomen (10\%), vomiting and convulsions were $9 \%$, pica were $7 \%$, swelling of face, limbs and abdomen were $6 \%$, generalized weakness were $5 \%$, passing worms and loose stools were $4 \%$, pallor, decreased appetite and weight, bleeding per rectum were $2 \%$, meningitis, delayed milestones and chest pain were $1 \%$.

Among 100 children it was observed that 57 children had hemoglobin \% of more than $10 \mathrm{gm}$ and 43 were anemic having hemoglobin of less than $10 \mathrm{gm} \%$.

Among 100 children peripheral smear revealed normocytic normochromic blood picture in $55 \%$, microcytic hypochromic anemia in $40 \%$ and normocytic hypochromic anemia in $5 \% .1 \%$ had thrombocytopenia.

In the present study, ZPP $>35$ ugm/dl was observed in 37 children and ZPP $<35$ ugm/dl was observed in $63 \%$.

In the present study among 100 children the blood lead levels estimated revealed that less than $10 \mathrm{ugm} / \mathrm{dl}$ were $17 \%$, between 15 - $19 \mathrm{ugm} / \mathrm{dl}$ and 25 - $54 \mathrm{ugm} / \mathrm{dl}$ were 6\%, more than or 
equal to $70 \mathrm{ugm} / \mathrm{dl}$ were $4 \%$, between $10-14 \mathrm{ugm} / \mathrm{dl}$ were $2 \%$, between $20-24 \mathrm{ugm} / \mathrm{dl}$ and between 55- $69 \mathrm{ugm} / \mathrm{dl}$ were $1 \%$.

\begin{tabular}{|l|l|l|l|}
\hline \multicolumn{1}{|c|}{ Investigation } & & \multicolumn{1}{c|}{$\%$} & Test of significance \\
\hline $\mathrm{Hb} \%$ & $<10$ & 43 & \\
\hline & $>10$ & 57 & $\mathrm{P}<0.001$ \\
\hline Peripheral smear & NNBP & 55 & $\mathrm{P}<0.001$ \\
\hline & MHA & 40 & \\
\hline & NHA & 05 & \\
\hline Thrombocytopenia & & 01 & $\mathrm{P}<0.001$ \\
\hline ZPP & $<35$ ugm/dl & 63 & $\mathrm{P}<0.001$ \\
\hline & $>35$ ugm/dl & 37 & $\mathrm{P}<0.001$ \\
\hline MEAN(SD) & & 43.35 & \\
\hline Blood lead levels ugm/dl & $<10$ & 17 & $\mathrm{P}<0.001$ \\
\hline & $10-14$ & 2 & NS \\
\hline & $15-19$ & 6 & NS \\
\hline & $20-24$ & 4 & NS \\
\hline & $25-54$ & 6 & NS \\
\hline & $55-69$ & 1 & NS \\
\hline & $>70$ & 4 & NS \\
\hline & \multicolumn{2}{|l}{}
\end{tabular}

DISCUSSION: Lead is not a body constituent .There is no biologic function for lead .There is no such thing as "safe" or acceptable level of lead. The lead level in blood should be zero. ${ }^{7}$

Earlier the mortality rate was high with lead toxicity. In 1930s and 1940s lead intoxication was treated with large doses of calcium and vitamin D enriched milk. In 1940s British Anti -Lewisite (BAL) was introduced as chelating agent. In early 1950s calcium disodium edentate was introduced Mortality rate was reduced with effective treatment. Studies showed that children who survived acute intoxication were often left with devastating deficits in intellectual function (ATSDR - 1988) and impairment in cognitive and behavior development (National Research Council, 1993).1, 2, 4

Largest study published in 1966, followed 425 surviving lead poisoned children and found that 39\% had neurological sequelae. Mental retardation, seizures, cerebral palsy and optic atrophy were also found. Of the group of people who had no symptoms but diagnosed as lead poisoning on the basis of high blood lead level alone showed 9\% mental retardation. (Nutrition News 1997).

Though treatment with EDTA, DMSA, BAL has been recommended, primary prevention of exposure to lead is important .To eradicate childhood lead poisoning, lead hazards must be abated.7

CONCLUSION: The study revealed important aspects; socio economic status affects lead exposure with poor socio economic status group being most prone for lead absorption.

Presenting symptoms were vague in children with fever and cough being the most common.

Among 20\% children who had high blood lead levels, 9\% had blood lead levels between 10 $24 \mathrm{ugm} / \mathrm{dl}$ who needed education regarding the source of exposure of lead and $7 \%$ of them had blood 
lead levels between 25 - 69 ugm/dl who needed not only education, close monitoring of blood lead levels, treatment of anemia and follow up .4\% needed acute medical management.

As lead poisoning patients can be asymptomatic or symptomatic with only vague presentations, screening of blood lead levels should be made as a routine investigation. Awareness should be created regarding the sources of lead, its exposure and potential health effects.

\section{REFERENCES:}

1. ATSDR (Agency for Toxic Substances and Disease Registry); Case Studies in Environmental Medicine; Lead Toxicity .Atlanta: 1990, 1992, 1998, 2000.

2. Bellinger D, Leviton A, Waternaux C, Needleman H, Rabinowitz M. Low Lead Level Exposure and Children's Cognitive Function in the Preschool Years. Paediatrics.1991:87:219-27.

3. Demographic and Health Surveys 2004.Measure DHS+. Description of the demographic and health surveys individual recode data file. Version 1.0. Available: http://www.measuredhs.com/

4. Bellinger D, Leviton A, Waternaux C, Needleman H, Rabinowitz M. Longitudinal Analysis Of Prenatal and Postnatal Lead Exposure and Early Cognitive Development. N Engl J Med 1987: 316: 1037-43.

5. AIIMS 1999 .Validation Of Lead Care Instrument. New Delhi: All India Institute of Medical Sciences.

6. CDC (Centres for Disease Control); Preventing Lead Poisoning in Young Children: A Statement by the CDC; Atlanta: 1985, 1978, 1991.

7. Aposhian H. V, Aposhian M.M. Meso-2, 3-Dimercaptosuccinic Acid; Chemical Pharmacological and Toxicological Properties of an Orally Effective Metal Chelating Agent. Ann Rev Pharmacol Toxicol: 1990: 30: 279-306.

\section{AUTHORS:}

1. Chandrakala P.

2. A. C. Ramesh

3. Sharanya R.

\section{PARTICULARS OF CONTRIBUTORS:}

1. Associate Professor, Department of Paediatrics, Kempegowda Institute of Medical Sciences and Research Centre.

2. Head of Department, Department of Paediatrics, Kempegowda Institute of Medical Sciences and Research Centre.

3. Post Graduate, Department of Paediatrics, Kempegowda Institute of Medical Sciences and Research Centre.

\section{NAME ADDRESS EMAIL ID OF THE CORRESPONDING AUTHOR:}

Dr. Chandrakala $P$, No. 376, 7h $^{\text {Th }}$ Cross, BCC Layout, Vijayanagar, Bangalore -40.

E-mail: drchandra89@gmail.com

Date of Submission: 07/02/2014.

Date of Peer Review: 08/02/2014.

Date of Acceptance: 25/02/2014.

Date of Publishing: 11/03/2014. 